\title{
Two species of Arboridia (Auchenorrhyncha: Cicadellidae) new to Fennoscandia
}

\author{
Anders Endrestøl
}

\begin{abstract}
Endrestøl, A. 2011: Two species of Arboridia (Auchenorrhyncha: Cicadellidae) new to Fennoscandia. - Entomol. Fennica 22: 65-68.

With Arboridia parvula (Boheman, 1845) one species of the genus Arboridia Zachvatkin, 1946 (Auchenorrhyncha: Cicadellidae) has been reported from Fennoscandia so far. This paper reports on two additional species of this genus in Fennoscandia: A. erecta (Ribaut, 1931) and A. pusilla (Ribaut, 1936). A. pusilla has never been recorded from Northern Europe. Both species probably have a very restricted distribution in Fennoscandia.
\end{abstract}

A. Endrestøl, Norwegian Institute for Nature Research, Gaustadalléen 21, NO0349 Oslo, Norway; E-mail: anders.endrestol@nina.no

Received 5 April 2011, accepted 9 May 2011

\section{Introduction}

In her monograph of the genus Arboridia Zachvatkin, 1946, Dworakowska (1970) lists 33 species worldwide (including Erythroneura defecta (Dlabola, 1957), now A. defecta), 15 of them from Europe. Nast $(1972,1987)$ lists 32 species from the Palaearctic (excluding Erythroneura lawsoniana $=$ Arboridia (Erythridula) dorsalis (Gillette, 1898) comb. n. Dworakowska 1970) and - based on Dworakowska (1970) - 15 species from Europe. Two species described from Asia have recently been discovered in Europe. $A$. loginovae (Emeljanov, 1964), previously only known from Altai Mts. and Kazakhstan (Dworakowska 1970), has been reported from the Czech Republic (Lauterer 2000). A. kakogawana (Matsumura, 1932), previously only known from Japan and Korea (Dworakowska 1970), has recently been found to be a pest on grapevine in southern Russia (Gnezdilov et al. 2008). Two new Arboridia species have also been described from Europe after Dworakowska (1970). One was described from Strandža in Bulgaria in 1987
(A. strandjensis Bayryamova, 1987) and another one was described from France in 1999 (A. pititia Della Giustina, Remane \& Wilson, 1999). Nickel (2003) considers the species $A$. versuta (Melichar, 1897), the holotype of which is a female, as dubious and reintroduces $A$. spathulata (Ribaut, 1931) previously treated as a junior synonym of $A$. versuta by Dworakowska (1970). Both species are erroneously treated as valid by Jach (2010). Nast (1987) discusses a possible synonymy of $A$. simillima (Wagner, 1939) and $A$. potentillae (Moravskaja, 1948). Another synonym of $A$. simillima might be $A$. loginovae (Emeljanov, 1964) (H. Nickel pers. comm.). If considering all three as valid, there are now 19 European species within the genus Arboridia.

According to Ossiannilsson (1981), only one species of the genus is found in Fennoscandia and Denmark, namely Arboridia parvula (Boheman, 1845). This is confirmed in the latest catalogue of the Auchenorrhyncha of Northern Europe (Söderman et al. 2009). This catalogue lists four species of Arboridia from Northern Europe, all except the widely distributed $A$. parvula are found 
only in the Baltic countries (Latvia and Lithuania). Dworakowska (1970) and Nast (1972) list A. ribauti (Ossiannilsson, 1937) from Sweden, but this has been omitted in later works (Nast 1987, Ossiannilsson 1983, Söderman et al. 2009).

Since 2003, the Norwegian Institute for Nature Research (NINA) has directed the project "Red-listed species - Survey and Monitoring" (ARKO) as a part of the government-initiated "National Program for Survey and Monitoring Biodiversity", the main target of which has been to identify important habitat types (hot-spot habitats) for threatened species (Sverdrup-Thygeson et al. 2007, 2009). A substantial amount of data has been recorded about rare and threatened species, including many species which previously never have been recorded from Norway or Scandinavia (Ødegaard et al. 2009).

One of the hot-spot habitats defined within the ARKO project is dry, calcareous meadows, a habitat known to harbour many rare and threatened species (Endrestøl et al. 2005, 2006, 2007). Here I report on two new Arboridia species to Fennoscandia, which were found in the Oslofjord region in Norway in material collected in this habitat type.

\section{Material and methods}

In 2009, three localities of dry, calcareous meadows in three different islands/peninsulas in the Oslo-fjord region where investigated using a base-line trap design of two Malaise traps, two intercept traps and 20 pitfall traps in each area. The traps were mounted at the beginning of May and checked once a month until the beginning of September. All specimens listed below were caught using Malaise-traps with a preservative fluid consisting of two-thirds propylene glycol and onethird water. Coordinates (decimal degrees) are given for the centre of the localities, with the Malaise traps no more than $50 \mathrm{~m}$ away. If nothing else is mentioned, leg./det. A. Endrestøl, coll. NINA.

\section{Results}

Leafhoppers of the genus Arboridia are very similar in their morphology. Males can be separated by the shape of the aedeagus and styles (Bieder- mann \& Niedringhaus 2004), but females cannot be distinguished morphologically (Aguin Pombo 2001, Nickel 2003). Therefore, female records are listed at the end. On at least one locality both species coexist.

\subsection{Arboridia erecta (Ribaut, 1931) $\widehat{ึ}$}

Norway, Akershus county, Bærum municipality, Ostøya (Ringerikshaugene), $59.86668 \mathrm{~N}$ 10.58245E: 06.V.-03.VI.2009, 1ठ; 29.VII.02.IX.2009, $3 \hat{\jmath} \widehat{\jmath}$

$A$. erecta is polyphagous on deciduous trees and shrubs. Most host plants belong to the families Fagaceae, Corylaceae, Aceraceae and Rosaceae (Aguin Pombo 2001, Nickel 2003). I found adults in V and VIII, which is consistent with other literature (Aguin Pombo 2001, Nickel 2003). A. erecta is thermophilous (Nickel 2003). European records are from central and southern parts, and it was recently published new to the Iberian Peninsula (Aguin Pombo 2001). It was reported new to Germany in 1996 (Heller 1996) and according to Nickel (2003) at its northern edge of its range there with only four known localities from the country. In addition to the records published here, the only Northern European record is from Latvia (Söderman et al. 2009).

\subsection{Arboridia pusilla (Ribaut, 1936) $\lesssim \precsim$}

Norway, Akershus county, Bærum municipality, Ostøya (Ringerikshaugene), $59.86668 \mathrm{~N}-$ 10.58245E: 06.V.-03.VI.2009, 1ठ; 24.VI.-

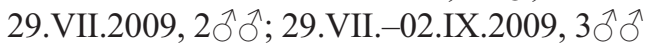

Norway, Oslo county, Oslo municipality, Bleikøya, 59.8905N-10.743E: 05.V.-02.VI.

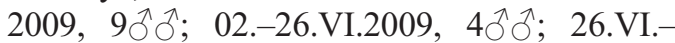
28.VII.2009, 9 ठึં; 28.VII.-01.IX.2009, $15 \hat{\jmath}$

Host plants given by Dworakowska (1970) are Geranium sanguineum, Ulmus campestris (= U. minor), Prunus spinosa and Prunus cerasus. A. pusilla is in Germany strictly confined to Geranium sanguineum (Nickel 2003). Both Norwegian localities given above have $G$. sanguineum (teste Endrestøl), and it is suspected that this is the host plant in Norway. This species is thermo- 
philous and German records are restricted to warm regions in southern parts of the country (Nickel 2003). European records are from central parts (Austria, Belgium, Bulgaria, Corsica, Czech Republic, Germany, Hungary, Russia Central, Switzerland, Ukraine and former Yugoslavia) (Jach 2010). It is also listed from France according to Nast (1987). This species is new to Northern Europe according to Söderman et al. (2009).

\subsection{Arboridia sp./spp. $q \circ$}

Norway, Akershus county, Bærum municipality, Ostøya (Ringerikshaugene), $59.86668 \mathrm{~N}-$ 10.58245E: 06.V.-03.VI.2009, $6 \circ$ 우 03.-24.VI. 2009, 3 우; 24.VI.-29.VII.2009, 1 q; 29.VII.02.IX.2009, 3 우

Norway, Oslo county, Oslo municipality, Bleikøya, $59.8905 \mathrm{~N}-10.743 \mathrm{E}: \quad 05 . \mathrm{V} .-02 . \mathrm{VI}$. 2009, 5ㅇ; 02.-26.VI.2009, $3 \circ 9$; 26.VI.28.VII.2009, 5우우 28.VII. 01.IX.2009, 14우우

Norway, Østfold county, Moss municipality, Jeløya [NE], 59.50219N-10.66622E: 05.VI.01.VII.2009, 3 우 (leg. A. Endrestøl \& T. J. Olsen)

\section{Discussion}

Dry, calcareous meadows in the Oslo-fjord region are found at bedrock of Cambro-Silurian origin, in a zone between the sea and forested inland areas. The habitat is frequently exposed to drought, due to a combination of high soil drainage and exposure to wind and sun. This results in a diverse and specialized flora and fauna, both as a combination of the soils and the relatively high overall temperatures (Fjellberg et al. 2010). This habitat type has mostly been destroyed on the mainland as a result of urbanization and other anthropogenic influences, but is still present in several islands and peninsulas in the inner Oslo fjord area due to less anthropogenic pressure. Fragmentation of these habitats is likely to be more severe for monophagous herbivores and species with reduced dispersal abilities (Steffan-Dewenter \& Tscharntke 2002), which is true for many of the Auchenorrhyncha species (e.g. Nickel 2003).
The findings of Arboridia erecta and A. pusilla from Norway were not expected as they both are known as thermophilic species from Central Europe (H. Nickel pers. comm.). Even so, the characteristics of the areas described above are evidently suitable for these species, both regarding host plants and climate, and underline the role of the calcareous meadows in inner Oslo fjord basin as a hot-spot for biodiversity, both in a national and international perspective. Even though the host plants of the both species are present along other parts of the Norwegian coastline, it is unlikely that they have a broader range in Norway than in the inner Oslo fjord area due to their climatic constrains. They are probably not undersampled, and even though they might be present in additional areas in southern parts of Fennoscandia (e.g. southern Sweden), it is unlikely that they are widely distributed in this region.

Including the records reported here, there are now a total of three species of Arboridia in Fennoscandia and five in northern Europe.

Acknowledgements. Thanks to Dr. Herbert Nickel and two referees for valuable comments on the manuscript. This study was funded by the government-initiated 'National Program for Surveys and Monitoring of Biodiversity Threatened species'.

\section{References}

Aguin Pombo, D. 2001: Arboridia erecta Ribaut, 1931 (Hemiptera: Cicadellidae) a new leafhopper to the fauna of the Iberian Peninsula and data on the distribution of Arboridia parvula (Boheman, 1845). — Zoologia Baetica 12: 101-107.

Biedermann, R. \& Niedringhaus, R. 2004: Die Zikaden Deutschlands - Bestimmungstafeln für alle Arten. Wissenschaftlich Akademischer Buchvertrieb-Fründ, Scheeßel. 409 pp.

Dworakowska, I. 1970: On the genus Arboridia Zachv. (Auchenorrhyncha, Cicadellidae, Typhlocybinae). Bulletin de l'Academie Polonaise des Sciences. Serie des sciences biologiques 18: 607-615.

Endrestøl, A., Gammelmo, Ø., Hansen, L. O., Lønnve, O. J., Olberg, S. \& Aarvik, L. 2005: Registrering og overvåking av utvalgte insektarter i Oslo kommune 2005 (Survey and monitoring of selected insect species in Oslo municipality 2005). - National Center for Insect Biodiversity. Report, Natural history museum, Oslo. 69 pp. [In Norwegian.]

Endrestøl, A., Gammelmo, Ø., Hansen, L. O., Lønnve, O. 
J., Olberg, S., Olsen, K. M. \& Aarvik, L. 2006: Registrering og overvåking av utvalgte insektarter i Oslo kommune 2006 II (Survey and monitoring of selected insect species in Oslo municipality 2006 II). - National Center for Insect Biodiversity. Report, Natural history museum, Oslo. $69+25$ pp. [In Norwegian.]

Endrestøl, A., Gammelmo, Ø., Hansen, L. O., Lønnve, O. J., Olberg, S., Olsen, K. M. \& Aarvik, L. 2007: Registrering og overvåking av utvalgte insektarter i Oslo kommune III (Survey and monitoring of selected insect species in Oslo municipality 2007 III). - National Center for Insect Biodiversity. Report, Natural history museum, Oslo. 66+31 pp. [In Norwegian.]

Fjellberg, A., Branderud, T. E., Elven, R. \& Ødegaard, F. 2010: The coast and the littoral zone. — In: Kålås, J. A., Henriksen, S., Skjelseth, S. \& Viken, Å. (eds.), Environmental conditions and impacts for Red List species. Norwegian Biodiversity Informastion Centre, Norway. $136 \mathrm{pp}$.

Gnezdilov, V. M., Sugonyaev, E. S. \& Artokhin, K. S. 2008: Arboridia kakogawana: a new pest of grapevine in southern Russia. - Bulletin of Insectology 61: 203-204.

Heller, F. 1996: Vier für Deutschland neue Zikaden. Megadelphax haglundi (J. Sahlbg.), Arboridia erecta (Rib. 1931), Fruticidia sanguinosa (Rey 1891) und Recilia horvathi (Then 1896) (Homoptera: Auchenorrhyncha). - Mitt. ent. Ver. Stuttgart 31: 112-116.

Jach, M. 2010: Fauna Europaea: Cicadellidae. — In: Hoch, H. (ed.), Fauna Europaea: Cicadomorpha. Fauna Europaea version 2.4. [www document]. URL http://www.faunaeur.org/. (Site visited on 30 Mars, 2011)

Lauterer, P. 2000: First reports of some leafhoppers (Auchenorrhyncha: Cicadellidae) from the Czech Republic and notes from Slovakia. - Acta Musei Moraviae, Scientiae biologicae (Brno) 85: 327-332.

Nast, J. 1972: Palaearctic Auchenorrhyncha (Homoptera). An annotated check list. — Polish Scientific Publications, Warszawa. 550 pp.
Nast, J. 1987: The Auchenorrhyncha (Homoptera) of Europe. - Annales Zoologici Polska Akademia Nauk 40: 535-661.

Nickel, H. 2003: The Leafhoppers and Planthoppers of Germany (Hemiptera, Auchenorrhyncha): Patterns and strategies in a highly diverse group of phytophagous insects. - Pensoft Publishers, Sofia-Moscow \& Goecke \& Evers, Keltern. 460 pp.

Ødegaard, F., Sverdrup-Thygeson, A., Hansen, L. O., Hanssen, O. \& Öberg, S. 2009: Survey of invertebrates in five hot-spot habitat types. Red-listed species and new species for Norway. 2004-2008. — NINA Report 500. 102 pp. [In Norwegian.]

Ossiannilsson, F. 1981: The Auchenorrhyncha (Homoptera) of Fennoscandia and Denmark. - Fauna Entomologica Scandinavica 7: 223-593.

Ossiannilsson, F. 1983: The Auchenorrhyncha (Homoptera) of Fennoscandia and Denmark. - Fauna Entomologica Scandinavica 7: 594-979.

Söderman, G., Gillerfors, G. \& Endrestöl, A. 2009: An annotated catalogue of the Auchenorrhyncha of Northern Europe (Insecta, Hemiptera: Fulgoromorpha et Cicadomorpha). - Cicadina 10: 33-69.

Steffan-Dewenter, I. \& Tscharntke, T. 2002: Insect communities and biotic interactions on fragmented calcareous grasslands - a mini review. - Biological Conservation 104: 275-284.

Sverdrup-Thygeson, A., Blom, H. H., Brandrud, T. E., Bratli, H., Skarpaas, O. \& Ødegaard, F. 2007: Survey and monitoring of red-listed species. Sub-project II: Red-listed species - survey and monitoring. Progress report 2006. - NINA report 238. 86 pp. [In Norwegian.]

Sverdrup-Thygeson, A., Bakkestuen, V., Bjureke, K., Blom, H., Brandrud, T. E., Bratli, H., Endrestøl, A., Framstad, E., Jordal, J. B., Skarpaas, O., Stabbetorp, O. E., Wollan, A. K. \& Ødegaard, F. 2009: Survey and monitoring of red-listed species. Progress report 2009. — NINA Report 528. 76 pp. [In Norwegian.] 